\title{
OVERMACHT: \\ ANALISIS YURIDIS PENUNDAAN PELAKSANAAN PRESTASI AKIBAT PANDEMI COVID-19
}

\author{
Tauratiya \\ Fakultas Syariah dan Ekonomi Islam, IAIN Syaikh Abdurrahman Siddik Bangka Belitung \\ Jalan Raya Petaling, KM.13, Kabupaten Bangka, Provinsi Kepulauan Bangka Belitung \\ Email: tauratiya@iainsasbabel.ac.id
}

\begin{abstract}
On March 14, 2020, the government of the Republic of Indonesia established the Covid-19 pandemic as a National Disaster. The whole community was asked to stay at home or work from home. This situation causes the daily activities of the community and government from school, work, trade, and others to become ineffective and delayed. This also affects all national and global corporate activities. Many business entities are disrupted due to the Large-Scale Social Limitation policy, so the company or a person cannot keep their promises as made in the previous agreement. This study examines whether Pandemic Covid-19 can be used as a reason for a person or a company to postpone the performance of achievements because it is considered as an overmacht, and how the legal force. This is a qualitative-library research using a juridical-normative approach. The results showed that overmacht is equated with the term force majeure meaning the state of force, in this case the debtor cannot be held accountable, because the situation occurs outside his control and not because of an element of negligence. The state of overmacht is regulated in the provisions of Article 1244 and Article 1245 of the Civil Code. Covid-19 pandemic is considered as a forced condition, including the overmacht category, so that it can be used as an excuse for debtors to postpone or not carry out performance according to the agreement, provided that the debtor is able to provide reasons that the failure to fulfill the agreement is not because of him, but because something cannot be predictable, and inevitable.
\end{abstract}

Keywords: Covid-19, Overmacht, Law, Agreement

\begin{abstract}
Abstrak: Tanggal 14 Maret 2020, pemerintah Republik Indonesia menetapkan pandemi Covid-19 sebagai Bencana Nasional. Seluruh masyarakat diminta untuk berdiam diri dirumah atau kerja dari rumah. Keadaan ini menyebabkan aktivitas kegiatan sehari-hari masyarakat dan pemerintahan mulai dari sekolah, bekerja, berdagang, dan lainnya menjadi tidak efektif dan tertunda. Ini berdampak pula pada semua aktivitas korporasi nasional maupun global. Banyak entitas bisnis terganggu akibat adanya kebijakan Pembatasan Sosial Berskala Besar, sehingga perusahaan atau seseorang tidak dapat menepati janjinya sebagaimana yang sudah dibuat dalam perjanjian sebelumnya. Oleh sebab itu, muncul pertanyaan, dapatkah Pandemi Covid-19 dijadikan sebagai alasan seseorang atau suatu perusahaan untuk menunda pelaksanaan prestasi karena dianggap sebagai suatu overmacht, dan bagaimana kekuatan hukumnya?. Hasilnya, overmacht disamakan dengan istilah force majeure artinya keadaan memaksa, dalam hal ini debitur tidak dapat dimintakan pertanggungjawabannya, sebab keadaan tersebut terjadi di luar kendalinya dan bukan karena unsur kelalaian. Keadaan overmacht diatur dalam ketentuan Pasal 1244 dan Pasal 1245 KUHPerdata. Pandemi Covid-19 dianggap sebagai suatu keadaan memaksa, termasuk kategori overmacht, sehingga dapat dijadikan alasan bagi debitur untuk menunda atau tidak melaksanakan prestasi sesuai perjanjian, dengan ketentuan debitur tersebut mampu memberikan alasan bahwa kegagalan memenuhi perjanjian bukan karena dirinya, melainkan karena sesuatu yang tak dapat diprediksi, dan tak dapat dihindarinya.
\end{abstract}

Kata kunci: Covid-19, Overmacht, Hukum, Perjanjian

\section{Pendahuluan}

Corona Virus Disease atau lebih dikenal dengan Covid-19 bukan hanya menjadi ancaman di Negara-negara luar, melainkan menjadi ancaman bagi masyarakat Indonesia beberapa bulan ini. Berdasarkan data yang dilansir dari laman Kawal Covid-19 atau kawalcovid19.id, hingga tanggal 02 April 2020 setidaknya ada 1.677 pasien yang positif terkena covid-19 di Indonesia, sebanyak 1.417 pasien masih dirawat, 
103 pasien yang dinyatakan sembuh, dan 157 pasien yang meninggal dunia. ${ }^{1}$

Covid-19 merupakan wabah virus mematikan yang pada tanggal 14 Maret 2020 ditetapkan Pemerintah sebagai Bencana Nasional. Pengumuman tersebut disampaikan oleh Presiden Republik Indonesia melalui Kepala Badan Nasional Penanggulangan Bencana (BNPB) di Gedung BNPB Jakarta. ${ }^{2}$ Aturan tentang Bencana Nasional terdapat pada Undang-Undang Nomor 24Tahun 2007 tentang Penanggulangan Bencana, dimana dalam ketentuan Pasal 1 ayat 1 dijelaskan bahwa pengertian Bencana adalah suatu peristiwa atau serangkaian peristiwa yang mengancam dan mengganggu kehidupan serta penghidupan masyarakat baik disebabkan oleh factor alam dan atau bukan factor alam, maupun faktor manusia sehingga menyebabkan timbulnya korban jiwa, kerusakan lingkungan, kerugian harta benda, dan dampak psikologis.

Penularan Covid-19 yang sangat cepat dan mudah antara orang satu dengan lainnya, ancaman risiko kematian bagi orang dewasa berusia diatas 50 tahun atau orang dengan daya tahan tubuh yang lemah, serta belum ditemukannya obat untuk menghadapi virus Covid-19 membuat banyak negara dan pemerintahan mengambil kebijakan yang berkaitan secara hukum, seperti lockdown atau social distancing. Pemerintah meminta seluruh masyarakat untuk stay at home (berdiam diri di rumah)atau work from home (kerja dari rumah). Keadaan ini menyebabkan aktivitas kegiatan seharihari masyarakat dan pemerintahan mulai dari sekolah, bekerja, berdagang, dan lainnya menjadi tidak efektif dan tertunda. Pandemi Covid-19 tidak hanya berdampak pada masyarakat akibat dari tidak dapat bekerja efektif, bahkan dampak yang sangat besar dirasakan pada semua aktivitas korporasi baik nasional maupun global.

1 "Hasil Riset Terbaru: Puncak Penyebaran Virus Corona Tak Lama Lagi, Jadwal Pandemi Covid-19 Berakhir", tribuntimur.com, https://makassar.tribunnews.com/2020/04/02/ hasil-riset-terbaru-puncak-penyebaran-virus-corona-tak-lamalagi-jadwal-pandemi-covid-19-berakhir, diakses pada tanggal 02 April 2020, Pukul 19.07 WIB.

${ }^{2}$ Dikutip dari rilis resmi Kementerian Kesehatan RI www. kemkes.go.id, pada tanggal 04 April 2020, Pukul 13.25 WIB.
Akibat dari penyebaran Covid-19 ini membuat beberapa Negara menutup akses masuknya warga negara lain maupun impor barang-barang tertentu yang berasal dari wilayah epidemic, seperti Indonesia yang pada tanggal 7 Februari 2020 telah resmi menerbitkan Peraturan Menteri Perdagangan No.10/2020 tentang Larangan Sementara Impor Binatang Hidup dari Tiongkok. Beberapa pabrik di Tiongkok ditutup sementara sebagai respon dari adanya wabah Covid-19. Diperkirakan banyak entitas bisnis terganggu akibat adanya kebijakan lockdown dan social distancing, sehingga perusahaan atau seseorang tidak dapat menepati janjinya sebagaimana yang sudah dibuat dalam perjanjian sebelumnya. Salah satu contoh misalnya pengiriman barang dari daerah satu ke daerah lainnya di Indonesia terkendala karena adanya pembatasan transportasi, dan menerapkan lockdown sebagaimana arahan pemerintah, sehingga barang tersebut tidak dapat dikirimkan sesuai dengan jadwal yang diperjanjikan. Dari contoh kasus di atas menimbulkan kemungkinan besar, bahwa Pandemi Covid-19 menyebabkan banyak kontrak perjanjian atau transaksi bisnis yang tertunda.

Ketentuan Pasal 1313 KUHPerdata menjelaskan bahwa perjanjian merupakan suatu perbuatan dimana seseorang atau lebih bersedia mengikatkan dirinya kepada orang lain atau lebih. Perjanjian dalam hubungan kerja dapat pula diartikan sebagai hubungan antara seseorang yang bertindak sebagai pekerja atau buruh dengan seseorang yang bertindak sebagai majikan. ${ }^{3}$ Isi dari perjanjian adalah prestasi yang harus dipenuhi para pihak, dimana kreditur memiliki hak atas suatu prestasi yang disepakati, sedangkan debitur memiliki kewajiban untuk melaksanakan prestasi tersebut, sehingga yang menjadi objek dari perjanjian adalah prestasi itu sendiri. Dalam suatu perjanjian, para pihak berhak untuk menentukan prestasinya berupa hak dan kewajiban yang mereka tulis dalam bentuk pasal-pasal atau klausul-klausul, dimana dalam pasal atau klausul tersebut menjelaskan

3 Wiwoho Soedjono, Hukum Perjanjian Kerja (Jakarta: Rineka Cipta, 1991), h. 9. 
tentang aturan bagi si pembuat perjanjian dalam menjalani hubungan hukum mereka untuk mencapai tujuan yang disepakati.

Kebebasan para pihak untuk menentukan isi perjanjian atau prestasi dikarenakan adanya freedom of contract atau asas kebebasan berkontrak yang tercermin dalam ketentuan pasal 1338 ayat (1) KUHPerdata. Didalam Pasal tersebut dijelaskan bahwa semua perjanjian yang dibuat secara sah, berlaku mengikat sebagai UndangUndang bagi para pihak yang membuatnya. Tiap orang dapat membuat perjanjian-perjanjian baru, baik hukum perjanjian bernama yang dikenal dalam undang-undang dan yang isinya dapat pula menyimpang dari perjanjian bernama yang diatur oleh Undang-Undang. ${ }^{4}$

Dalam perspektif hukum perjanjian, kegagalan memenuhi prestasi atau memenuhi kewajiban sebagaimana kesepakatan diistilahkan dengan wanprestasi. Akan tetapi dalam hukum, wanprestasi dapat dibenarkan apabila seseorang atau perusahaan yang tidak memenuhi kewajiban atau prestasi sesuai dengan perjanjian dapat membuktikan adanya suatu keadaan yang menghalangi dan tidak dapat dihindari, serta bukan disebabkan oleh kesengajaan dari seseorang atau perusahaan tersebut, misanya bencana alam, kebakaran, dan sebagainya. Halangan yang tidak dapat dihindari yang bukan disebabkan oleh kesengajaan manusia dalam hukum perjanjian diistilahkan dengan Overmacht atau keadaan memaksa.

Overmacht menurut doktrin dari ahli hukum diartikan sebagai suatu keadaan tidak terduga yang menghalangi debitur untuk melaksanakan prestasi atau kewajibannya sesuai dengan kesepakatan yang diperjanjikan, dan keadaan ini benar-benar tidak dapat dihindari debitur. Keadaan atau peristiwa tersebut tidak dapat dipertanggungjawabkan kepada debitur, sementara debitur tersebut tidak beriktikad buruk.

Berdasarkan uraian diatas, maka muncul pertanyaan apakah Pandemi Covid-19 dapat

${ }^{4}$ J. Satrio, Hukum Perikatan (Perikatan pada Umumnya) (Bandung: Alumni, 1999), h. 36. dijadikan sebagai alasan seseorang atau suatu perusahaan untuk menunda pelaksanaan prestasi karena dianggap sebagai suatu overmacht, dan bagaimana kekuatan hukumnya?

\section{Metode Penelitian}

Penelitian ini merupakan penelitian yuridis normatif dengan pendekatan kualitatif. Penelitian yuridis normatif merupakan penelitian hukum yang menggunakan literature sebagai sumber data atau dikenal pula sebagai penelitian kepustakaan. ${ }^{5}$

Data utama penelitian ini berupa bahanbahan kepustakaan yang terdiri dari UndangUndang, literatur, buku-buku lain yang berkaitan dengan penelitian ini, yaitu meliputi:

a) Bahan Hukum Primer

Bahan hukum primer berupa peraturan perundang-undangan atau peraturan lain yang memiliki kekuatan mengikat dan bersifat autoritatif. ${ }^{6}$

b) Bahan Hukum Sekunder

Bahan hukum sekunder berupa artikel ilmiah, buku-buku ilmu hukum yang memberikan penjelasan mengenai bahan hukum primer. ${ }^{7}$

c) Bahan Hukum Tersier

Bahan hukum tersier berupa kamus hukum, ensiklopedia, dan sebagainya yang menjelaskan bahan hukum primer dan sekunder. ${ }^{8}$

\section{Analisis Penundaan Pelaksanaan Prestasi Akibat Covid-19 Sebagai Suatu Overmacht}

Ketentuan Pasal 1338 ayat 1 KUHPerdata menjelaskan bahwa suatu perjanjian mempunyai kekuatan mengikat sebagai suatu aturan atau Undang-Undang, bahkan sebagai lex specialis

\footnotetext{
${ }^{5}$ Soerjono Soekanto dan Sri Mamudji, Penelitian Hukum Normatif(Jakarta: PT. Raja Grafindo Persada, 2001), h. 13.

6 Piter Mahmud Marzuki, Penelitian Hukum (Jakarta: Kencana, 2005), h. 140.

${ }^{7}$ Amiruddin dan Zainal Asikin, Pengantar Metode Penelitian Hukum (Jakarta: PT. Raja Grafindo Persada, 2012), h. 32.

8 Mukti Fajar ND dan Yulianto Achmad, Dualisme Penelitian Hukum Normatif dan Empiris (Yogyakarta: Pustaka Pelajar, 2010), h. 157-158.
} 
terhadap ketentuan umum bagi para pihak yang membuat dan menandatangani perjanjian tersebut. ${ }^{9}$ Pasal tersebut juga menujukkan bahwa hukum perjanjian menganut sistem terbuka (opened system), sehingga memberi kebebasan sebesar-besarnya kepada setiap orang untuk mengadakan perjanjian, sepanjang tidak melanggar Undang-Undang, kesusilaan dan ketertiban umum. ${ }^{10}$ Dalam membuat suatu perjanjian, para pihak harus memperhatikan dan memenuhi syarat-syarat suatu perjanjian yang diatur dalam Pasal 1320 KUHPerdata, yaitu cakap/dewasa; kata sepakat; objek jelas; dan causa yang halal.

Tidak semua maksud dan tujuan yang lahir dari hubungan hukum suatu perjanjian dapat selalu terlaksana, peristiwa tersebut terjadi akibat wanprestasi atau ingkar janji baik yang dilakukan kreditur maupun debitur, adanya paksaan, kekeliruan, perbuatan curang, maupun keadaan yang memaksakan atau dikenal dalam hukum Indonesia dengan overmacht. Dampak dari munculnya keadaan ini menyebabkan suatu perjanjian dapat dibatalkan atau batal demi hukum. ${ }^{11}$ Dalam perjanjian, overmacht (keadaan memaksa) menjadi salah satu klausa yang tidak pernah dilupakan, hal ini dikarenakan kedudukannya dalam suatu perjanjian yang berada pada perjanjian pokok dan tidak terpisahkan sebagai suatu perjanjian tambahan atau perjanjian baru, serta dikaitkan dengan perjanjian pokok selayaknya perjanjian accesoir. ${ }^{12}$

Riduan Syahrani menjelaskan bahwa dalam kamus hukum, istilah overmacht berasal dari

\footnotetext{
9 Ricardo Simanjuntak, Akibat Dan Tindakan-Tindakan Hukum Terhadap Pencantuman Klausula Baku Dalam Polis Asuransi Yang Bertentangan Dengan Pasal 18 Undang-Undang No.8/1999 Tentang Perlindungan Konsumen, Jurnal Hukum Bisnis, Vol. 22, No. 2 (2003), h. 56.

${ }^{10}$ Subekti, Aneka Perjanjian (Bandung: Citra Aditya Bakti, 1995), h. 3.

${ }^{11}$ Elly Erawati, Herlien Budiono, Penjelasan Hukum Tentang Kebatalan Perjanjian (Jakarta: Nasional Legal Reform ProgramGramedia, 2010), h. 5.

${ }^{12}$ Perjanjian accesoir ialah perjanjian yang sifatnya tambahan dan bergantung kepada perjanjian pokoknya, contohnya suatu perjanjian pinjam-meminjam dengan jaminan, dimana dalam hal ini perjanjian pinjam-meminjam merupakan perjanjian pokok, sedangkan jaminan merupakan perjanjian tambahannya.
}

bahasa Belanda yang berarti keadaan memaksa, yaitu keadaan yang menghalangi penunaian perikatan yang membebaskan seseorang dari kewajiban mengganti biaya, kerugian dan bunga. ${ }^{13}$ Selain itu, overmacht juga diartikan sebagai suatu keadaan yang merajalela dan menyebabkan orang tidak dapat menjalankan tugas dan kewajibannya, dan dalam bahasa Perancis dikenal dengan istilah Force Majeure yang memiliki arti yang sama.

Overmacht menurut doktrin dari ahli hukum diartikan sebagai suatu keadaan tidak terduga yang menghalangi debitur untuk melaksanakan prestasi atau kewajibannya sesuai dengan kesepakatan yang diperjanjikan, dan keadaan ini benar-benar tidak dapat dihindari debitur. Keadaan atau peristiwa tersebut tidak dapat dipertanggungjawabkan kepada debitur, sementara debitur tersebut tidak beriktikad buruk. Hal ini tertuju pada keadaan yang diakibatkan oleh bencana alam atau kecelakaankecelakaan yang terjadi di luar kemampuan manusia dan tidak dapat dihindari, sehingga debitur tidak mungkin untuk memenuhi isi perjanjian, contohnya pelaksanaan prestasi tidak sesuai dengan waktu yang sudah disepakati, atau objek yang diperjanjikan telah musnah. Keadaan memaksa dibedakan menjadi dua macam, yaitu absolut onmogelijkheid (keadaan memaksa yang absolut) dan relatieve onmogelijkheid (keadaan memaksa yang relatif). ${ }^{14}$

Absolut onmogelijkheid atau keadaan memaksa yang absolut merupakan suatu keadaan atau peristiwa dimana debitur sama sekali tidak dapat memenuhi prestasinya, hal ini biasanya disebabkan oleh karena adanya banjir bandang, gempa bumi, dan adanya lahar akibat gunung meletus. Sedangkan, relatieve onmogelijkheid atau keadaan memaksa yang relatif merupakan suatu keadaan atau peristiwa yang menyebabkan debitur mungkin untuk melaksanakan prestasinya, meskipun pemenuhan prestasi dilakukan dengan memberikan korban yang besar yang tidak seimbang atau menggunakan kekuatan jiwa yang

13 Riduan Syahrani, Seluk Beluk dan Asas-asas Hukum Perdata (Bandung: Alumni, 2006), h. 243.

${ }^{14}$ Subekti, Hukum Perjanjian (Jakarta: Intermasa, 1987), h. 56. 
di luar kemampuan manusia atau kemungkinan tertimpa bahaya kerugian yang sangat besar.

Adanya sifat mutlak dan relatif overmacht menunjukkan pembedaan antara keduanya.Sifat mutlak dikaitkan dengan pembatalan atau batal terhadap suatu kewajiban debitur dikarenakan musnahnya objek perjanjian, sedangkan relatif yang diartikan dengan gugur menunjukkan prestasi dapat dilakukan oleh debitur, tetapi tidak memiliki nilai dalam pandangan kreditur. ${ }^{15}$ Abdulkadir Muhammad merinci sifat mutlak dan relatif overmacht sebagai berikut: ${ }^{16}$

1. Keadaan yang menunjukkan sifat mutlak dari keadaan memaksa yaitu keadaaan atau peristiwa yang menunjukkan prestasi tidak dapat dipenuhi karena suatu hal yang memusnahkan, membinasakan, dan menghancurkan objek dari perjanjian.

2. Keadaan yang dapat bersifat mutlak atau relative yaitu keadaaan atau peristiwa yang menunjukkan prestasi tidak dapat dipenuhi karena suatu hal yang dapat menghalangi perbuatan debitur untuk memenuhi prestasi.

3. Keadaan yang menunjukkan bahwa kesalahan tidak berada pada kedua belah pihak khususnya debitur yaitu keadaan yang tidak pasti, karena tidak dapat diketahui atau diduga akan terjadi oleh kreditur atau debitur pada saat mengadakan perjanjian.

Terdapat dua teori yang membahas tentang keadaan memaksa, yaitu teori objektif dan teori subjektif. Dalam teori objektif, dijelaskan bahwa suatu keadaan menyebabkan tidak mungkin untuk melakukan prestasi yang diperjanjikan karena ketidak mampuan debitur untuk menghadapi kenyataan tersebut, atau dengan kata lain debitur dapat mengemukakan tentang keadaan memaksa apabila pemenuhan prestasinya bagi setiap orang mutlak tidak mungkin dilaksanakan. Dalam hal ini, debitur sama sekali tidak mungkin melakukan

15 Abdulkadir Muhammad, Hukum Perdata Indonesia, (Bandung: Alumni, 1993), h. 206.

${ }_{16}$ Abdulkadir Muhammad, Hukum Perikatan (Bandung: Citra Aditya Bakti, 1992), h. 28. prestasinya pada kreditur. Contohnya, dalam penyerahan sebuah rumah oleh debitur tidak dapat dilaksanakan karena rumah tersebut telah musnah akibat bencana alam atau kejadian lainnya. Selanjutnya, teori ini berkembang menjadi teori yang tidak lagi hanya berpegang pada suatu ketidakmungkinan yang mutlak, melainkan juga teori ini menganggap bahwa suatu keadaan dianggap sebagai keadaan memaksa apabila barang atau objek perjanjian tersebut hilang atau di luar perdagangan. ${ }^{17}$ Sedangkan, dalam teori subjektif dijelaskan bahwa suatu keadaan memaksa apabila terjadi keadaan memaksa pada debitur mengingat keadaan pribadinya tidak dapat memenuhi prestasinya, maka terhapuslah keadaan debitur tersebut. Berdasarkan teori ini, maka debitur tidak dapat dimintai pertanggungjawaban oleh kreditur karena tidak menyebabkan kesalahan apapun. Dalam hal ini ajaran subjektif mengakui adanya keadaan memaksa, tetapi jika ini menyangkut industry besar maka tidak dikenal adanya suatu keadaan memaksa. ${ }^{18}$

Keadaan memaksa dikaitkan pula dengan teori penghapusan atau peniadaan kesalahan (afwesigheid van schuld), dimana teori ini memberikan keringanan kepada debitur untuk tidak bertanggungjawab terhadap suatu kewajiban yang seharusnya dilakukan, karena kesalahan tersebut bukan berasal dari debitur. Teori ini menjelaskan bahwa debitur tidak perlu membayar ganti rugi,selain itu beban resiko tidak berubah terutama pada keadaan memaksa sementara, serta kecuali terhadap Pasal 1460 KUHPerdata, kreditur tidak berhak atas pemenuhan prestasi, tetapi bersamaan dengan pembebasan dari kewajibannya untuk menyerahkan kontra prestasi. ${ }^{19}$

Overmacht difokuskan pada suatu keadaan atau peristiwa yang terjadi di luar kemampuan debitur dan menghalanginya untuk memenuhi

${ }^{17}$ Sukarmi, Cyber Law: Kontrak Elektronik dalam Bayangbayang Pelaku Usaha, (Bandung: Pustaka Sutra, 2008), h. 39

${ }^{18}$ Sukarmi, Cyber Law..., h. 40.

19 Salim, Erlies Septiana Nurbani, Perbandingan Hukum Perdata Comparative Civil Law, (Jakarta: Rajawali Pers, 2014), h. 264. 
prestasi, bukan suatu keadaan yang secara sengaja dibuat atau timbul karena suatu kelalaian yang disebabkan oleh tindakan debitur atau adanya vreemde oorzak (sebab luar). ${ }^{20}$

Pasal 1244 KUHPerdata berbunyi:

"Jika ada alasan untuk itu si berhutang harus dibukum mengganti biaya, rugi dan bunga, bila ia tidak membuktikan, bahwa hal tidak dilaksanakan atau tidak pada waktu yang tepat dilaksanakannya perjanjian itu, disebabkan karena suatu hal yang tak terduga, pun tak dapat dipertanggungjawabkan padanya, kesemuanya itu pun jika itikad buruk tidak ada pada pihaknya."

Pasal 1245 KUHPerdata berbunyi:

"Tidaklah biaya, rugi dan bunga harus digantinya, apabila karena keadaan memaksa (overmacht) atau karena suatu keadaan yang tidak disengaja, si berutang berhalangan memberikan atau berbuat sesuatu yang diwajibkan, atau karena hal-hal yang sama telah melakukan perbuatan yang terlarang."

Berdasarkan ketentuan Pasal 1244 dan 1245 KUHPerdata yang menjadi landasan hukum overmacht telah ditetapkan bahwa keadaan memaksa dijadikan sebagai alasan hukum yang membebaskan debitur dari kewajibannya untuk melaksanakan prestasi atau melaksanakan pemenuhan (nakoming) dan ganti rugi (schadevergoeding), meskipun debitur telah melakukan perbuatan melanggar hukum/ onrechtmatigedaad. ${ }^{21}$

Purwahid Patrik mengemukakan syarat diberlakukannya suatu keadaan memaksa, yaitu adanya suatu halangan dalam memenuhi kewajiban, halangan tersebut muncul bukan disebabkan atas kesalahan debitur atau resiko debitur. ${ }^{22}$ Sedangkan, R. Subekti dalam Amran Suadi menyatakan overmacht terjadi karena keadaan tesebut terjadi diluar kekuasaan debitur dan memaksa, keadaan tersebut merupakan suatu keadaan yang tidak dapat diketahui terjadinya pada saat perjanjian itu dibuat, dan setidak-

${ }^{20}$ M. Yahya Harahap, Segi-Segi Hukum Perjanjian, (Bandung: Alumni, 1982), h. 89-90.

${ }^{21}$ M. Yahya Harahap, Segi-Segi..., h. 82-98

22 Purwahid Patrik, Dasar-Dasar Hukum Perikatan (Perikatan yang lahir dari perjanjian dan Undang-Undang), (Bandung: Mandar Maju, 1994), h. 18. tidaknya resiko tidak dipikul oleh debitur. ${ }^{23}$ Keadaan memaksa memiliki unsur-unsur yaitu: peristiwa atau keadaan yang tidak terduga; tidak dapat dipertanggungjawabkan kepada debitur; tidak ada itikad buruk dari debitur; adanya keadaan yang tidak disengaja oleh debitur; keadaan itu menghalangi debitur berprestasi; jika prestasi dilaksanakan maka akan terkena larangan; keadaan di luar kesalahan debitur; debitur tidak gagal berprestasi (menyerahkan barang); kejadian tersebut tidak dapat dihindari oleh siapa pun; debitur tidak terbukti melakukan kelalaian atau kesalahan. Dengan terpenuhinya unsur-unsur keadaan memaksa tersebut, maka debitur tidak diwajibkan untuk membayar ganti rugi, dan dalam hal perjanjian timbal balik, kreditur tidak dapat menuntut pembatalan karena perikatannya dianggap gugur atau terhapus. Akan tetapi, berdasarkan ketentuan Pasal 1444 ayat 1 dan ayat 4 KUHPerdata, dijelaskan pula tentang pemenuhan ganti rugi yang berbunyi:

1. Jika barang tertentu yang menjadi pokok persetujuan musnah, tak dapat diperdagangkan, atau hilang hingga tak diketahui sama sekali apakah barang itu masih ada, atau tidak, maka hapuslah perikatannya, asal barang itu musnah atau hilang di luar kesalahan debitur dan sebelum ia lalai menyerahkannya.

2. Dengan cara bagaimanapun suatu barang hilang atau musnah, orang yang mengambil barang itu sekali-kali tidak bebas dan kewajiban untuk mengganti harga.

Hal inilah yang menyebabkan keadaan memaksa disebut sebagai rechtvaardigings-grond atau dasar hukum yang membenarkan. Istilah overmacht tidak hanya dikenal dalam ranah Hukum Perdata saja, melainkan terdapat pula dalam Pasal 48 dan Pasal 49 Kitab Undangundang Hukum Pidana (KUHP), dimana dijelaskan bahwa seorang tertuduh tidak boleh dihukum apabila tindak pidana yang dilakukannya itu dalam keadaan overmacht. Dari

23 Amran Suadi, Penyelesaian Sengketa Ekonomi Syariah (Penemuan dan Kaidah Hukum), (Jakarta: Prenadamedia Grup, 2018), h. 116. 
ketentuan pasal tersebut, dapat disimpulkan bahwa dalam hukum pidanapun suatu perbuatan yang onrechtmatigedaad, tetapi dilakukan di bawah tekanan atau pengaruh overmacht akan melepaskan si pelanggar dari tuntutan.

Pasal atau klausul yang mengatur tentang keadaan memaksa atau overmacht dalam sebuah perjanjian adalah hal yang sudah biasa ada. Dalam hukum perjanjian, segala hal yang telah disepakati para pihak akan menjadi hukum yang mengikat para pembuatnya. Apabila dalam hal ini para pihak tidak mencantumkan klausula keadaan memaksa atau overmacht dalam perjanjian, maka dapat mengacu pada ketentuan dalam Pasal 1245 KUHPerdata yang sifatnya melengkapi isi perjanjian, dengan syarat debitur harus mampu membuktikan kegagalannya memenuhi prestasi diakibatkan peristiwa tidak terduga atau diluar kehendaknya. Timbul masalah baru apabila para pihak mengatur sebaliknya dalam suatu klausula perjanjian, yaitu tidak memasukkan epidemi penyebaran virus menjadi salah satu jenis dari keadaan overmacht, sehingga hal ini tidak bias digolongkan sebagai keadaan memaksa.

Dengan penetapan Covid-19 sebagai Bencana Nasional pada tanggal 14 Maret 2020. Achmad Yurianto sebagai Juru Bicara Pemerintah untuk kasus Covid-19tanggal 15 Maret 2020 diKomplek Istana Negaramenjelaskan bahwa berdasarkan ketentuan Undang-Undang Nomor 24 Tahun 2007 tentang Penanggulangan Bencana, terdapat tiga jenis bencana yang dibedakan dalam aturan ini, yaitu Bencana Alam, Bencana Nonalam, dan Bencana Sosial.Penyebaran virus Covid-19 dikategorikan kedalam jenis bencana nonalam. Pengertian bencana non alam dalam Pasal 1 ayat 3 Undang-Undang Penanggulangan Bencana diartikan sebagai suatu bencana yang diakibatkan oleh peristiwa atau serangkaian peristiwa non alam yang disebabkan beberapa hal misalnya gagal teknologi, gagal modernisasi, epidemi, dan wabah penyakit.

Adanya regulasi yang dikeluarkan oleh pemerintah yang berwenang dan kebijakan pemerintah daerah maupun nasional yang memberlakukan lockdown atau social distancing, pembatasan jalur masuk antar daerah, serta meminta seluruh masyarakat untuk stay at home (berdiam diri dirumah)atau work from home (kerja dari rumah) secara langsung menghambat pelaksanaan prestasi atau kewajiban dalam suatu kontrak perjanjian, sehingga menyebabkan hal ini dapat digolongkan dalam keadaan memaksa atau overmahcht. Terhalangnya suatu pihak untuk memenuhi prestasi akibat kondisi ini termasuk dalam keadaan keadaan memaksa atau overmahcht, sehingga risiko yang ditimbulkan karenanya ditanggung bersama oleh para pihak dalam perjanjian, kecuali sudah ditentukan dan diatur siapa yang menanggung risiko jika terjadi keadaan memaksa atau overmacht oleh para pihak.

Dari beberapa pendapat para ahli hukum Indonesia dapat disimpulkan bahwa Pandemi Covid-19 dianggap sebagai suatu keadaan memaksa atau overmacht, sehingga dapat dijadikan alasan bagi debitur untuk menunda atau tidak melaksanakan prestasi sesuai perjanjian, dengan ketentuan debitur tersebut mampu memberikan alasan bahwa kegagalan memenuhi perjanjian bukan karena dirinya, melainkan karena sesuatu yang tak dapat diprediksi, dan tak dapat dihindari yaitu Covid-19. Contohnyayaitu dalam perjanjian jual beli melalui situs perbelanjaan online yg ada di Indonesia, dimana setelah kreditur membayar sejumlah uang untuk barang yang dipesannya, debitur memiliki kewajiban untuk mengirimkan barang tersebut pada tanggal yang sudah diperjanjikan, dan harus sampai pada tanggal yang sudah disepakati. Dalam kasus ini, debitur sudah mengirimkan barang sesuai dengan tanggal yang sudah ditentukan, akan tetapi karena adanya pembatasan penerbangan di setiap bandara di provinsi-provinsi Indonesia akibat Pandemi Covid-19, barang yang dikirimkan tidak dapat diterima kreditur sesuai dengan tanggal yang telah disepakati. Dalam hal ini, kreditur tidak dapat menuntut pertanggungjawaban debitur tersebut, akan tetapi debitur tersebut harus mampu memberikan alasan bahwa kegagalan memenuhi perjanjian bukan karena dirinya, melainkan karena sesuatu yang tak dapat diprediksi, dan tak dapat dihindari yaitu akibat dari pembatasan karena Covid-19. Untuk menghindari sengketa, 
para pihak dapat mengambil langkah yang salah satunya dengan melakukan renegosiasi perjanjian atau mengatur ulang prestasi yang harus dilakukan sampai kondisi kembali normal.

\section{Penutup}

Overmacht (keadaan memaksa) dalam sebuah perjanjian menjadi salah satu klausa yang tidak pernah dilupakan, hal ini dikarenakan kedudukannya dalam suatu perjanjian berada pada perjanjian pokok, tidak terpisah sebagai suatu perjanjian tambahan dan dikaitkan dengan perjanjian pokok selayaknya perjanjian accesoir. Adanya regulasi terkait Pandemi Covid-19 yang dianggap sebagai Bencana Nasional yang dikeluarkan oleh pemerintah berwenang, serta kebijakan pemerintah daerah maupun nasional yang memberlakukan lockdown atau social distancing, pembatasan jalur masuk antar daerah, serta meminta seluruh masyarakat untuk stay at home (berdiam diri dirumah)atau work from home (kerja dari rumah) secara langsung mengakibatkan terhambatnya pelaksanaan prestasi atau kewajiban debitur dalam suatu kontrak perjanjian. Terhalangnya suatu pihak untuk memenuhi prestasi akibat kondisi ini termasuk dalam keadaan memaksa atau overmahcht, sehingga risiko yang ditimbulkan karenanya ditanggung bersama oleh para pihak dalam perjanjian, kecuali sudah ditentukan dan diatur siapa yang menanggung risiko jika terjadi overmacht oleh para pihak.

\section{Pustaka Acuan}

Asikin, Zainal dan Amiruddin. Pengantar Metode Penelitian Hukum, Jakarta: PT. RajaGrafindoPersada, 2012.

Erawati, Elly, Herlien Budiono. Penjelasan Hukum Tentang Kebatalan Perjanjian, Jakarta: Nasional Legal Reform ProgramGramedia, 2010.

Fuady, Munir. Hukum Kontrak (dari Sudut Pandang Hukum Bisnis), Bandung: Alumni, 2003.

Harahap, M. Yahya. Segi-Segi Hukum Perjanjian. Bandung: Alumni, 1982.

Marzuki, Peter Mahmud. Penelitian Hukum, Jakarta: Kencana, 2005.
Muhammad, Abdulkadir. Hukum Perdata Indonesia, Bandung: Alumni, 1993.

Fajar, Mukti dan Yulianto Achmad ND. Dualisme Penelitian Hukum Normatif dan Empiris, Yogyakarta: Pustaka Pelajar, 2010.

Nurbani, Erlies Septiana dan Salim. Perbandingan Hukum Perdata Comparative Civil Law, Jakarta: Rajawali Pers, 2014.

Patrik, Purwahid. Dasar-Dasar Hukum Perikatan (Perikatan yang lahir dari perjanjian dan Undang-Undang), Bandung: Mandar Maju, 1994.

Satrio, J. Hukum Perikatan, Perikatan pada Umumnya, Bandung: Alumni, 1999.

Soedjono, Wiwoho. Hukum Perjanjian Kerja. Jakarta: Rineka Cipta, 1991.

Soekanto, Soerjono dan Sri Mamudji. Penelitian Hukum Normatif, Jakarta: PT. Raja Grafindo Persada, 2001.

Soemadipradja dan Rahmat S.S. Penjelasan Hukum tentang Keadaan Memaksa. Jakarta: Nasional Legal Reform Program-Gramedia, 2010.

Suadi, Amran. Penyelesaian Sengketa Ekonomi Syariah (Penemuan dan Kaidah Hukum), Jakarta: Prenadamedia Grup, 2018.

Subekti. Aneka Perjanjian. Bandung: Citra Aditya Bakti, 1995.

Subekti. Hukum Perjanjian. Jakarta: Intermasa, 1987.

Sukarmi, Cyber Law: Kontrak Elektronik dalam Bayang-bayangPelaku Usaha, Bandung: Pustaka Sutra, 2008.

Syahrani, Riduan. Hukum Perikatan, Bandung: Citra Aditya Bakti, 1992.

Syahrani, Riduan. Seluk Beluk dan Asas-asas Hukum Perdata, Bandung: Alumni, 2006.

Waode, Desy Dwi Safitri. "Upaya Hukum Dan Penyelesaian Akibat Wanprestasi Serta Overmacht Dalam Perjanjian Pembiayaan", Dedikasi Jurnal Mahasiswa, Vol. 1, No. 1, 2018.

Simanjuntak, Ricardo. "Akibat Dan TindakanTindakan Hukum Terhadap Pencantuman Klausula Baku Dalam Polis Asuransi Yang Bertentangan Dengan Pasal 18 UndangUndang No.8/1999 Tentang Perlindungan Konsumen", Jurnal Hukum Bisnis, Vol. 22, No. 2, 2003. 